日本臨床麻酔学会第 32 回大会シンポジウム 日臨麻会誌 Vol.33 No.5, $770 \sim 774,2013$

痛みの医療における質問票を用いた評価法の有用性と限界 疼痛評価における心理的因子の評価の重要性

関口美穂 ${ }^{* 1}$ 紺野懭一 ${ }^{* 2}$

[要旨] 疼痛の増悪や遷延化には, 心理・社会的因子の関与, 具体的には心の健康度, ストレスや 仕事への満足度が, われわれに認識されていた以上に早期から関与している. すなわち, 心理・社 会的因子の早期評価が重要であり，「整形外科患者に対する精神医学的問題評価のための簡易質問 票」(Brief Scale for Psychiatric Problems in Orthopaedic Patients : BS-POP)がスクリ 一ニングには有用である. また, 脳器質異常や脳機能障害の存在にも留意する必要がある. 慢性疼 痛の患者では, 多職種により多面的に評価し, 治療目標を生活機能の改善に設定して治療を行うこ とが重要である.

キーワード : 慢性疼痛, 心理的問題, 整形外科患者に対する精神医学的問題評価のための簡易質問 票(BS-POP), 多面的評価

\section{はじめに}

慢性疼痛患者では，精神的健康度が低く治療難航

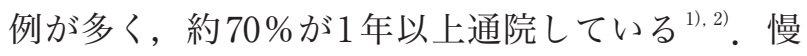
性疼痛の部位は, 腰部が最も多く, 次いで肩や頝部 であり，運動器疾患が慢性疼痛の原因のほとんどを 占めている ${ }^{2)}$. 運動器疾患は, 画像上の変化が症状 と必ずしも直結していないという事実に留意してお く必要がある。画像所見だけでは, 加齢性変化と病 的変化を区別することは不可能であり, 痛みの特徵 を聴取することにより原因疾患を推定し，見逃して はいけない重篤な疾患を見極める必要がある.特に, 高齢者の場合には，加齢性変化が著明であること， 長期に通院し薬物療法が行われていることが一般的 である，症状が慢性化する場合には，漫然と薬物の 投与を続けるのではなく，診断の再評価を行うこと
が重要である，特に，症状の時間的推移や精神的背 景は軽視される傾向があるので留意する。

\section{I 心理・社会的因子}

脊椎疾患, 特に腰椎疾患は, 他の運動器疾患と比 較して, 包括的 QOL 尺度である MOS 36-Item ShortForm Health Survey(SF-36)で, 心の健康(mental health)などの心理的下位尺度が有意に低下してい る ${ }^{3)}$. さらに，慢性疼痛患者の約 $25 \sim 75 \%$ に抑う つが存在し, 慢性疼痛患者の背景には，心理的因子 が関与する ${ }^{4)}$ ．腰痛関連機能障害の程度を評価する 腰痛に特異的な QOL 尺度として, Roland-Morris Disability Questionnaire (RDQ)が汎用されている. 質問は 24 項目からなり，高得点ほど日常生活の障 害の度合いが高いことを示す。腰痛の程度が強いほ ど，腰痛関連機能障害の程度が強くなると予測され

*1福島県立医科大学医学部附属実験動物研究施設

*2 福島県立医科大学医学部整形外科
著者連絡先 関口美穂

干 960-1295 福島県福島市光が丘 1

福島県立医科大学医学部附属 実験動物研究施設 
表 1a BS-POP 医師用：治療者に対する質問票

\begin{tabular}{|c|c|c|c|c|c|c|}
\hline 質問項目 & \multicolumn{6}{|c|}{ 回答と点数 } \\
\hline 1. 痛みのとぎれることがない & 1 & そんなことはない & 2 & 時々とぎれる & 3 & ほとんどいつも痛む \\
\hline 2. 患者の示し方に特徵がある & 1 & そんなことはない & & 患部をさする & & $\begin{array}{l}\text { 指示がないのに衣服を脱 } \\
\text { ぎ始めて患部を見せる }\end{array}$ \\
\hline 3. 患肢全体が痛む（しびれる） & 1 & そんなことはない & 2 & ときどき & 3 & ほとんどいつも \\
\hline $\begin{array}{l}\text { 4. 検査や治療をすすめられたとき, 不機 } \\
\text { 嫌, 易怒的, または理屈っぽくなる }\end{array}$ & 1 & そんなことはない & 2 & 少し拒否的 & 3 & おおいに拒否的 \\
\hline 5. 知覚検査で刺激すると過剩に反応する & 1 & そんなことはない & 2 & 少し過剩 & 3 & おおいに過制 \\
\hline 6. 病状や手術について繰り返し質問する & 1 & そんなことはない & 2 & ときどき & 3 & ほとんどいつも \\
\hline $\begin{array}{l}\text { 7. 治療スタッフに対して, 人を見て態度 } \\
\text { を変える }\end{array}$ & 1 & そんなことはない & 2 & 少し & & 著しい \\
\hline $\begin{array}{l}\text { 8. ちょっとした症状に, これさえなけれ } \\
\text { ばとこだわる }\end{array}$ & 1 & そんなことはない & 2 & 少しこだわる & 3 & おおいにこだわる \\
\hline
\end{tabular}

得点：回答番号の合計 (最低 8 点から最高 24 点)

る。しかしながら, 腰痛の程度が軽度であるにも関 わらず，QOL障害が強い対象者が存在する。その 要因は, 心の健康度が低い, ストレスがある, 仕事 への満足度が低い(職場環境, 収入, 人間関係)であ る ${ }^{5)}$.さらに, 近年, 非がん性疼痛にオピオイドが 適応になり, 運動器疾患に伴う疼痛に対しても汎用 されるようになってきた。精神疾患を併発している 患者では，依存形成のリスクが高いことが報告され ている ${ }^{6)}$. 精神的因子が併存する場合には，オピオ イドは有用ではない ${ }^{7)}$. 以上のことから, 慢性疼痛 患者では，心理・社会的因子の評価が重要といえる.

\section{II 精神医学的アプローチ}

当大学の整形外科と心身医療科では，1996年か らリエゾン精神医学的アプローチを導入し, 整形外 科患者で難治性の症状を有する患者に対して，合同 でカンファランスを行っている. カンファランスは 毎月 1 回開催し，対象症例は，慢性疼痛を有する整 形外科患者である。構成員は, 整形外科医, 心身医 療科医 (精神科医), 理学療法士, 看護師, 薬剂師, 臨床心理士である.慢性疼痛患者の治療においては, 身体的疾患, 精神的疾患, 社会的環境因子および心 理的因子を含む個人として，さらに，生活障害や生
活不安などの背景を含める多面的な評価が必要であ る。身体的疾患のみへの治療は無効である。症状の 発症から持続に関連する要因を明らかにした上で, 多職種からの治療に対する多面的アプローチが必要 である。

\section{III 精神医学的問題の評価}

よく知られている精神医学的問題の評価法は膨大 な質問内容であるため，精神医学専門以外の医師に とって，また，整形外科やペインクリニックを受診 している患者にとっては，実施に抵抗がある。さら には，その質問票の評価と解釈も容易ではない。わ れわれは，簡便でかつ多面的評価が可能な「整形外 科患者に対する精神医学的問題評価のための簡易質 問票」(Brief Scale for Psychiatric Problems in Orthopaedic Patients : BS-POP)を作成した ${ }^{8)}$ 。この 質問票は，医師用(表 1a) と患者用(表 1b)の 2 つで 構成されている。医師用は，医師に対する質問 8 項 目で，最低 8 点から最高 24 点である。患者用は, 患者自記式で質問 10 項目からなり，最低 10 点から 最高 30 点である. BS-POPのカットオフ值は，「医 師用のみで 11 点以上」または，「医師用で 10 点以 上かつ患者用で 15 点以上」のいずれかの場合に， 
表 1b BS-POP 患者用：患者に対する質問票

\begin{tabular}{|c|c|c|c|c|c|c|}
\hline 質問項目 & \multicolumn{6}{|c|}{ 回答と点数 } \\
\hline $\begin{array}{l}\text { 1. 泣きたくなったり，泣いたりすることが } \\
\text { ありますか }\end{array}$ & & いいえ & & ときどき & 3 & ほとんどいつも \\
\hline 2. いつもみじめで気持ちが浮かないですか & 1 & いいえ & 2 & ときどき & 3 & ほとんどいつも \\
\hline 3. いつも緊張して, イライラしていますか & 1 & いいえ & & ときどき & 3 & ほとんどいつも \\
\hline 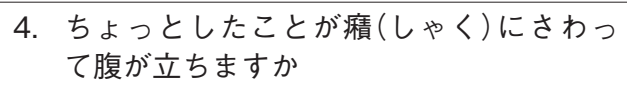 & & いいえ & & ときどき & 3 & ほとんどいつも \\
\hline 5. 食欲は普通ですか & 3 & いいえ & 2 & ときどきなくなる & 1 & ふつう \\
\hline $\begin{array}{l}\text { 6. } 1 \text { 日のなかでは, 朝方がいちばん気分がよ } \\
\text { いですか }\end{array}$ & 3 & いいえ & & ときどき & & ほとんどいつも \\
\hline 7. 何となく疲れますか & 1 & いいえ & 2 & ときどき & 3 & ほとんどいつも \\
\hline 8. いつもとかわりなく仕事ができますか & 3 & いいえ & 2 & ときどきやれなくなる & 1 & やれる \\
\hline 9. 睡眠に満足できますか & 3 & いいえ & 2 & ときどき満足できない & 1 & 満足できる \\
\hline 10. 痛み以外の理由で寝つきが悪いですか & 1 & いいえ & 2 & ときどき寝つきが悪い & 3 & ほとんどいつも \\
\hline
\end{tabular}

得点：回答番号の合計 (最低 10 点から最高 30 点)

精神医学的問題を有する可能性が高いと判定す る ${ }^{9)}$. さらに, 計量心理学的にBS-POPの検証を行 い，尺度として高い信頼性と再現性と妥当性を有し ていることを証明している ${ }^{10)}$ 。また, 慢性腰痛患者 のうち，80\%以上でBS-POPが高值であることが 明らかにされている ${ }^{11)}$. BS-POPでスクリーニング された慢性腰痛患者のうち，88\%が身体表現性障害 で，そのうち約半数が疼痛性障害である ${ }^{11}$. 以上の 結果から, 精神医学的問題をスクリーニングするこ とが必要で，BS-POPはその評価のために有用なツ ールといえる。

\section{IV 脳の器質的障害}

慢性疼痛患者において，脳血流の低下，前頭葉や 側頭葉の発育不全が $80 \%$ 以上で観察され，また脳 波異常は約 $90 \%$ に認められる。慢性疼痛患者は, なんらかの脳の器質障害を伴うことが多い ${ }^{11)}$.12)。ま た, 多動性障害や広汎性発達障害などの発達障害は, 30〜36\%に合併している，発達障害の存在自体が 慢性疼痛に関連している可能性が示唆される ${ }^{11), 12)}$. 慢性腰痛患者では, 機能的脳画像において, 健常者 と比較して後帯状回で脳賦活が有意に増強し, 不快
な痛みを感じている ${ }^{13)}$ 。これらの脳器質異常や脳機 能障害の存在は，横断的な検討であることから，慢 性疼痛との因果関係について不明であり, 今後, 縦 断的検討を行う必要がある。

\section{$\mathrm{V} \quad$ 治療とそのポイント}

整形外科疾患に対する治療において，その治療前 にBS-POPで高值の症例では，治療に対する満足 度が低い ${ }^{8)}$ ．また腰椎退行性疾患に対する手術成績 において，術前のBS-POPが高值であると，手術 に対する満足度が低く，術後の遺残症状の程度が強 い ${ }^{14)}$ ．BS-POPを用いると，治療に対する患者の満 足度も予測できる。慢性疼痛患者に対する整形外科

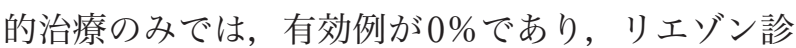
療により，有効例が約半数で，主訴である疼痛は不 変であるが治療を継続中が約 $40 \%$ である ${ }^{11,12}$. 慢 性疼痛に対する治療には，前述した多面的アプロー チが必要である(図1)。医療従事者側と患者との信 頼関係を含む人間関係が，治療効果や患者の満足度 に影響する，多面的な治療を実施する上では，医療 従事者のみが治療の主体的な役割を果たすのではな く，患者自身も治療方針の決定や治療に参加するこ 


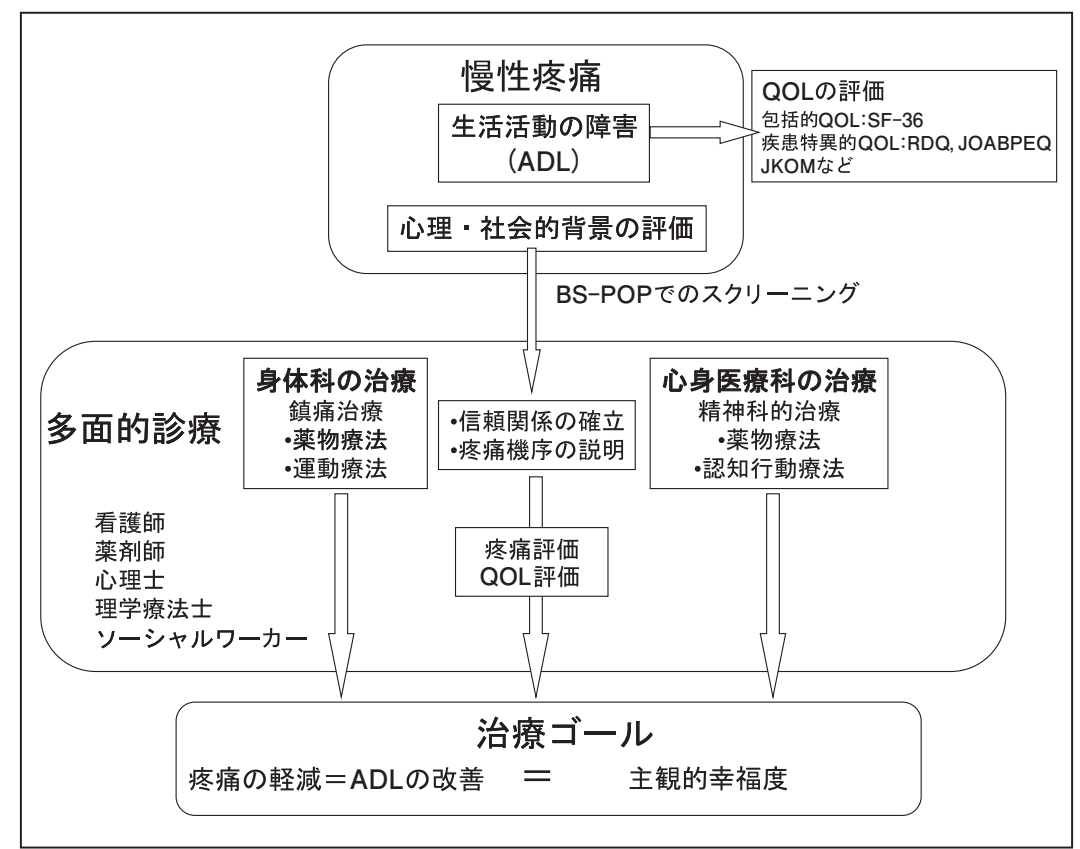

図1 慢性疼痛に対する治療に必要な多面的アプローチ

とが求められる。例えば，脳内におけるドパミンシ ステムの破綻などの慢性化している疼痛発生機序の 解説, 医療従事者からの助言による不安の除去, そ して社会的支援を含む職場や生活改善の指導などが 重要である。すなわち, 患者への情報提供, インフ オームドコンセントの実施，そして患者教育は必須 である。ささに, 疼痛性疾患治療の目的は, 疼痛を 除去することではなく，もとの健康な状態になるべ く早く復帰させることである.

\section{おわりに}

慢性疼痛では，心理・社会的因子の早期評価が重 要である。また，治療目標を生活機能の改善に設定 し，多面的アプローチによる治療が必要である.

\section{参考文献}

1）松平浩, 竹下克志, 久野木順一ほか：日本に打ける慢 性疼痛の実態一Pain Associated Cross-sectional Epidemiological(PACE) survey 2009. JP一. ペインクリニ ック $32: 1345-1356,2011$
2) Nakamura M, Nishiwaki Y, Ushida T, et al. : Prevalence and characteristics of chronic musculoskeletal pain in Japan. J Orthop Sci 16 : 424-432, 2011

3）中村英一郎, 大友一, 村岡静香ほか：腰痛の起源と疫 学 腰痛による quality of life (QOL) 損失の検討 他の運 動器疾患との比較. J Spine Res 2：1070-1075, 2011

4) Gallagher RM, Moore P, Chernoff I : The reliability of depression diagnosis in chronic low back pain. A pilot study. Gen Hosp Psychiarty 17 : 399-413, 1995

5) Takahashi N, Kikuchi S, Konno S, et al. : Discrepancy between disability and the severity of low back pain : demographic, psychologic, and employment-related factors. Spine $31:$ 931-939, 2006

6) Edlund MJ, Steffick D, Hudson T, et al. : Risk factors for clinically recognized opioid abuse and dependence among veterans using opioids for chronic non-cancer pain. Pain $129:$ 355-362, 2007

7) Chelminski PR, Ives TJ, Felix KM, et al. : A primary care, multi-disciplinary disease management program for opioid-treated patients with chronic non-cancer pain and a high burden of psychiatric comorbidity. BMC Health Serv Res $5: 2005$

8）佐藤勝彦, 菊地臣一, 増子博文ほか：脊椎・春䯣疾患 に対するリエゾン精神医学的アプローチ(第 2 報） 整形 外科患者に対する精神医学的問題評価のための簡易質 問票 (BS-POP)の作成．臨整外 $35 ： 843-852,2000$ 
9）渡辺和之, 菊地臣一, 紺野愼一ほか：整形外科患者に 対する精神医学的問題評価のための簡易質問票 (BSPOP)一妥当性の検討一. 臨整外 40：745-751，2005

10) Yoshida K, Sekiguchi M, Otani K, et al. : A validation study of the Blief Scale for Psychiatric problems in Orthopaedic Patients (BS-POP) for patients with chronic low back pain(verification of reliability, validity, and reproducibility). J Orthop Sci $16: 7-13,2011$

11）二階堂环也, 菊地臣一, 矢吹省司ほか：慢性腰痛に対 するリエゾンアプローチ，第 17 回日本腰痛学会, 2009
12）大谷晃司，菊地臣一，矢吹省司ほか：慢性疼痛患者の 特徵と精神科医との関わりーリエゾン診療から検討一. J Spine Res 1:439, 2010

13) Kobayashi Y, Kurata J, Sekiguchi M, et al. : Augmented cerebral activation by lumbar mechanical stimulus in chronic low back pain patients : an FMRI study. Spine 34 : 2431-2436, 2009

14）大谷晃司, 菊地臣一, 矢吹省司ほか：腰仙椎部退行性 疾患の手術成績と BS-POP との関係一前向き研究一. J Spine Res $2: 639$, 2011

\title{
The Clinical Significance of Evaluation of Psychosocial Factors in Pain Assessment
}

\author{
Miho SEKIGUCHI*1, Shinichi KONNO*2 \\ ${ }^{* 1}$ Laboratory Animal Research Center, Fukushima Medical University School of Medicine \\ ${ }^{* 2}$ Department of Orthopaedic Surgery, Fukushima Medical University School of Medicine
}

It is known that psychosocial factors such as mental health, stress and job satisfaction are strongly related to the onset of increase and chronicity of pain. Psychiatric problems should be evaluated from an early stage. The Brief Scale for Psychiatric Problems in Orthopaedic Patients (BS-POP) is a simple questionnaire and a useful tool for quick and easy evaluation to assess patients' psychiatric problems. In addition, the presence of structural disorders of the brain in chronic pain patients should be investigated. Multidisciplinary evaluation of various types is indispensable to assess a patient's background for chronic pain.

It is important to address psychological and social problems in order to relieve pain and improve quality of life from an early stage.

Key Words : Chronic pain, Psychiatric problem, The Brief Scale for Psychiatric Problems in Orthopaedic Patients : BS-POP, Multidisciplinary evaluation

The Journal of Japan Society for Clinical Anesthesia Vol.33 No.5, 2013 